\title{
"La plaga con que castiga Dios los pecados de los hombres": langosta y campo andaluz en la Edad Moderna
}

\author{
Milagros León Vegas* \\ UNIVERSIDAD DE MÁLAGA (ANDALUCÍA, ESPAÑA)
}

La creencia popular atribuye los crueles efectos ocasionados por las plagas de langosta a la gravedad de los delitos morales cometidos por la sociedad del momento. Sin embargo, factores climatológicos y geográficos determinarán la actuación y el progreso de un mal, al cual se combate desde la plegaria y los rudimentarios medios humanos de la época. Trasladar las características concretas de esta calamidad a un espacio-tiempo específico, como el sur de la Península Ibérica en las centurias de la modernidad, será nuestro principal objetivo.

(Langosta, religiosidad, endeudamiento vecinal, Andalucía, Antequera)

\section{Miedo ANTE UnA ADVERSIDAd SECUlaR: IMPRONTA EN FUENTES ESCRITAS}

4 1 título de este trabajo recoge la definición de langosta contenida en el Tesoro de la lengua castellana o española de Sebastián de Covarrubias y Orozco, publicado en $1611 .{ }^{1}$ Este erudito humanista conjuga, en su monumental diccionario, la acepción de la palabra con su propia reflexión y la percepción contemporánea del hecho descrito. En este caso, sintetiza perfectamente el impacto de los acrídidos sobre la mentalidad del hombre del Antiguo Régimen: aprensión a una fuerza destructora sobrenatural.

¿Qué sustento tiene tan insondable temor? Sin duda, su fiereza. La catástrofe, en sus distintas manifestaciones, amenaza a la Huma-

*milagros@uma.es

${ }^{1}$ Sebastián Covarrubias y Orozco, Tesoro de la lengua castellana o española, Madrid, Luis Sánchez, impresor del Rey N.S., 1611. 
nidad desde el principio de los tiempos. Partiendo de esta realidad, la langosta llega a ser, a lo largo de la historia, detonante de uno de los agentes de la tríada apocalíptica: el hambre. Sin embargo, lo nefasto de su aparición la convierte en precursora de los otros dos macabros jinetes: la guerra y la peste. Según determinados idearios ancestrales, la enfermedad infecciosa vendría propiciada por la descomposición orgánica de los insectos muertos-según ocurrió con el contagio del reino de Aragón, en 1495²-, mientras el conflicto bélico confirmaría los aciagos augurios de una plaga de insectos antecedente -auspiciando, por ejemplo, la llegada del turco otomano a Hungría y Polonia, en $1566^{3}$.

Su huella indeleble nos retrotrae a la Antigüedad. Observamos su representación en iconografía egipcia y asiria, en los textos bíblicos del Éxodo o en los primeros tratados de biología animal de Aristóteles (siglo Iv a. C.) y Plinio el Viejo (siglo I d. C.).

En España, San Isidoro de Sevilla incluye la acepción de langosta en sus Etimologías (627-630 d. C.). No obstante, será en la decimosexta centuria cuando los tratadistas humanistas añadan la consideración de "venganza divina" por los pecados de los impíos: Luis Vives, Arias Montano o Juan Bodino. ${ }^{4} \mathrm{El}$ atormentado espíritu barroco del siglo XVII seguirá impregnando numerosos escritos con esta simbólica maldición, atraída por el desliz moral del hombre. Por ejemplo, el obispo de Cádiz y Algeciras, José de Barcia y Zambrano, en su libro de sermones otorga a la langosta la categoría de "ministro por la indignación de Dios". 5 Lo diabólico de este "ser" lleva al citado metropolitano a establecer comparativas con otro género peligroso: la mujer; no solo por su naturaleza femenina, también por la obstinada tentación y la llamada al pecado suscitada en

${ }^{2}$ Gerónimo Zurita, Anales de la Corona de Aragón, Zaragoza, Herederos de Pedro Lanaja y Lamarca, 1610, tomo 5, libro 2, cap. 12.

${ }^{3}$ Ulisse Aldrovandi, De animalibus insectos libri septem cum singularum iconibus ad vivum expressis..., Bolonia, 1602, 10.

${ }^{4}$ De todo ello nos informa, ampliamente, Francisco Javier Peris Felipo, en su interesante trabajo: "Apuntes sobre la lucha contra la plaga de langosta en los siglos modernos", Tiempos Modernos (revista digital), 17, 2008/2.

${ }^{5}$ Joseph Barcia y Zambrano, Despertador Cristiano de sermones doctrinales sobre particulares assumptos, tomo III, Cádiz, Cristóbal de Requena Impresor, 1694, 234. 
determinadas ocasiones, como en los bailes profanos. Curiosas e insólitas semejanzas, formuladas en los siguientes términos: "Langostas, porque saltan sin rey y razón que las govierne; Langostas, por lo insaciable de su apetito vano; y langostas nocivas, porque destruyen con su provocación la hermosura de las mieses de la Iglesia". ${ }^{6}$

Sin embargo, en esa misma centuria, aparecen destacados escritos, más objetivos respecto al fenómeno, donde lo importante será el estudio del ciclo reproductor del animal y sus comportamientos, para así intentar prevenir su proliferación y el desastre. Entre ellos, la obra más recurrente durante toda la Edad Moderna, será la de Juan de Quiñones, de 1620. Este alcalde mayor de la villa de El Escorial y Juez de las obras y bosques Reales de San Lorenzo escribió, según él mismo indica en el título de su escrito, el tratado más "útil y necesario" para combatir la plaga, al menos, fue así durante varias centurias. ${ }^{7}$ La promoción a tan honorable puesto vino dada gracias a su loable actuación como corregidor en la villa de Huete (Cuenca), en concreto, durante la extinción de la langosta que asoló los campos manchegos en 1619. La practicidad de sus recomendaciones, sustentada en la experiencia directa y en la lectura de algunos textos clásicos y eruditos, suponen el conjunto de remedios utilizados en todo el suelo peninsular hasta la publicación de la Instrucción de 1755, ya en el siglo de las Luces. ${ }^{8}$

En la España del siglo xviII, la aparición de los acrídidos fue frecuente y especialmente virulenta en Andalucía, Castilla la Mancha y Extremadura. La sustitución de la dinastía de los Austrias por los Borbones, supuso una centralización política y administrativa del

${ }^{6}$ Ibidem, p. 353.

${ }^{7}$ Juan de Quiñones, Tratado de las langostas, muy útily necessario, en que se tratan cosas de provecho y curiosidad para todos los que profesan letras divinas y humanas, y las mayores ciencias..., Madrid, Luis Sánchez, impresor del Rey, 1620.

${ }^{8}$ Instrucción formada, sobre la experiencia, y practica de varios años, para conocer, y extinguir la langosta en sus tres estados de hovacion, feto, ò mosquito, y adulta: con el modo de repartir, y prorratear los gastos, que se hicieren en este trabajo, y aprobada por el consejo, año de mil setecientos y cinquenta y cinco. El texto consultado se incluye en la obra de: Pedro Boada de las Costas y Figueras, Adiciones y repertorio general de la práctica universal forense de los tribunales superior e inferior de España e Indias, Madrid, Imprenta Ramón Ruiz, 1793. 
país, perceptible en la normativa que se seguirá en todo tipo de asuntos, incluidas las medidas que se adoptarían en caso de presencia masiva de cigarrones. En dicho periodo, no vamos a encontrar disposiciones de la Corona para atajar el mal a escala concejil o municipal, sino una codificación detallada y general para todo el Reino. En este sentido, el Consejo de Castilla promulgó los ordenamientos del 11 de septiembre de 1723 y del 8 de junio de 1755 -este último corroborado el 18 de diciembre de 1804-, todos ellos incorporados en la Novísima recopilación de las Leyes de España, en 1805. ' Sin duda, el precepto de 1755 es primordial y en él, además de las cuestiones económicas para cubrir el costo del exterminio, se distinguen las tácticas que se emplearán para terminar con la langosta, según su estado biológico: ovación, mosquitos y saltones.

No podemos terminar este breve apartado sin mencionar la obra científica del ingeniero de minas irlandés Guillermo Bowles, publicada en Madrid en 1775, en la cual se compilan y difunden todos los conocimientos atesorados, hasta ese momento, sobre biología hispánica. ${ }^{10}$ En ella ofrece, entre otros datos, una detallada descripción de los ciclos de incubación y nacimiento de este tipo de acrídidos. ${ }^{11}$ Así, la fecundación y posterior alojamiento de su "semilla" en terrenos cálidos e incultos, se lleva a cabo por el mes de agosto. La hembra, ayudada de un poderoso aguijón trasero, dispone en la tierra una pequeña hendidura, enterrando allí sus huevos protegidos por una especie de fundilla o vaina. Si las lluvias no llegan a ser torrenciales, único factor inhibitorio junto a las heladas, en primavera los labrantíos podían verse invadidos de estos ortópteros, que poco tiempo después, en estado "adulto" y gregario, formarían una gran nube negra capaz de devastar kilómetros de cosechas.

El interés del texto de este naturalista ilustrado es incuestionable. Al comienzo del capítulo dedicado a las plagas padecidas en Espańa,

${ }^{9}$ Isabel Azcatare Luxan y Luis Maldonado Polo, "La plaga de la langosta y el tizón del trigo en la España ilustrada”, Llull, núm. 15, 1992, 318-319.

${ }^{10}$ Guillermo Bowles, Introducción a la Historia Natural y a la geografía física de España, Imprenta Real, Madrid, 1782, 269-270.

${ }^{11}$ Alberto Gomís, "La divulgación de la Historia Natural en la Espańa del siglo XviII", Actas VIII Congreso de la Sociedad Española de Historia de las Ciencias y de las Técnicas, Universidad de la Rioja, 2004, 318-119. 
consecutivamente desde 1754 a 1757, nos da la clave del porqué de tanta virulencia. Este voraz insecto habitaba los campos incultos del sur peninsular de forma permanente por su clima cálido y la inmensidad de sus dehesas. El mal latente subsistía imperceptible a los ojos del hombre pues, aunque advertían al saltón, su presencia era discreta y dispersa. Dicho descuido, unido a la fecundidad del acrídido, permitía la generación de grandes enjambres, los cuales, con la facilidad del vuelo, buscaban alimento más allá de las superficies desocupadas por el hombre, amenazando sus cultivos y, con ellos, la propia subsistencia de aquéllos.

Las Langostas de que voy a hablar se hallan continuamente en las partes meridionales de España, y en especial de las dehesas y tierras no cultivadas de Estremadura, pero no se repara en ellas, porque regularmente son en cantidad moderada, y viven de hiervas incultas, sin tocar los sembrados ni las huertas, ni entrar en las casas. Los paisanos las ven sin susto saltar y pacer la hierva de los prados, y esta indolencia suya les hace perder la ocasión favorable de exterminarlas todos los ańos; pero no reparan en ellas sino quando el estrago que hacen es tal que a veces no tiene remedio. ${ }^{12}$

Según Bowles, estamos ante un mal endémico de la mitad sur de España, que sólo adquiría dimensiones catastróficas por falta de previsión humana. En consecuencia, los testimonios escritos en torno a la existencia de langosta responden a los momentos más críticos de su actuación sobre los campos labrados por el hombre, entre ellos los andaluces. De dichas fuentes documentales nos valdremos para componer el presente estudio.

\section{ANDALUCÍA Y LAS PLAGAS DE LANGOSTA EN LA EDAD MODERNA: UNA APROXIMACIÓN}

La localización geográfica de un territorio lo condiciona a una climatología concreta y los agentes medioambientales derivados de la misma afectan, irremediablemente, a la comunidad humana que la

${ }^{12}$ Guillermo Bowles, op. cit., p. 257. 
habita. Partiendo de esta lógica premisa, resulta fácil entender el porqué de la proliferación de la langosta en el agro de la zona meridional de la Península. Dos factores son determinantes: las grandes extensiones incultas y las temperaturas cálidas. Estas últimas se deben a la situación de Andalucía en el extremo sur del continente europeo y a su clima mediterráneo, caracterizado por veranos secos y calurosos. Por otra parte, la expansión de las dehesas encuentra su origen en una fuerte tradición ganadera hispánica, alentada desde el periodo de la reconquista cristiana. La inseguridad de la fluctuante frontera con el Islam, convertía al pastoreo en una actividad económica segura, en comparación con una agricultura amenazada continuamente por las razias entre reinos cristianos y musulmanes. La institución, en el siglo XIII, del Honrado Concejo de la Mesta - gremio de ganaderos, con legislación y amplios privilegios concedidos por la Corona-, hasta su supresión en 1836, avala la importancia de este sector. Sin embargo, los pastos no van a servir sólo de sustento del ganado, también lo serán de parásitos destructivos. El aumento de la cabaña en la Edad Moderna lleva consigo la deforestación de buena parte de las arboledas de Extremadura y Andalucía, dónde los rebaños trashumantes del norte aprovechaban para pacer, de forma intensiva, de noviembre a mayo. Todo ello da como resultado grandes superficies de pastizales, con hendiduras de escasa profundidad, generadas por la acción animal. Un hábitat perfecto para anidar los huevos de la langosta, sobre todo, por la frecuente aridez del terreno.

Según los últimos estudios centrados en el siglo XviI, Andalucía encabeza la nómina de regiones afectadas en mayor número de ocasiones por el azote de tan temido saltón. En concreto, veinticinco años de dicha centuria estuvieron marcados por el infortunio, frente a los diecisiete de Extremadura o los nueve de Castilla La Mancha. ${ }^{13}$ De nuevo, estos tres territorios son los más perjudicados en el siglo XVIII, especialmente desde 1751 a 1757.

${ }^{13}$ Así lo recoge en su tesis doctoral, aún inédita: Juan Cosme Sanz Larroca, Las respuestas religiosas ante las plagas del campo en la España del siglo XVII, UNED, 2008, 453. El historiador arroja el siguiente número de años afectados por langosta, según comunidades: Andalucía: 25; Extremadura: 17; Canarias: 13; Murcia: 13; Aragón: 12; Segovia: 10; Cataluña: 9 y La Mancha: 9. 
No pretendemos hacer un recorrido exhaustivo por todos los episodios desastrosos generados por los acrídidos en Espańa, ni tan siquiera en el área andaluza, pero sí destacar los estudios más interesantes realizados, hasta el momento, desde la historiografía reciente. Centrándonos en el periodo conocido como Edad Moderna, escasas monografías abordan exclusivamente esta problemática -situación motivada, quizás, por el carácter excepcional y aislado del suceso, pese a su cíclica reaparición a lo largo del tiempo-, si bien, resulta de consideración casi obligada en trabajos dedicados al análisis de la economía del momento, por su estrecha e indisoluble vinculación con la agricultura. ${ }^{14}$ Será en la década de los noventa de la pasada centuria cuando encontremos publicaciones específicas sobre el tema. Destaca, por la amplitud cronológica y espacial, el artículo de Julián Montemayor sobre las plagas padecidas en el interior de España, desde el siglo XVI al siglo XVIII. ${ }^{15}$ Por otra parte, la proclividad atmosférica de las zonas cálidas para atraer a la langosta y el carácter mediterráneo del fenómeno, coloca al campo valenciano en un territorio altamente amenazado, a cuyo estudio se han consagrado las importantes investigaciones de Rubio Vela y, más recientemente, de Alberola Romá. ${ }^{16} \mathrm{La}$

${ }^{14}$ Sirva de ejemplo, el destacado trabajo de Gonzalo Anes, Las crisis agrarias en la España moderna, Taurus, Madrid, 1970. El historiador alude a las plagas de langosta como uno de los factores que explican las periódicas crisis de subsistencias soportadas a lo largo del Antiguo Régimen. Incluso en publicaciones más recientes, de carácter colectivo, centradas en el análisis de las amenazas del agro en los siglos precedentes, encontramos capítulos o artículos dedicados a la langosta, junto a otros temas como las adversidades meteorológicas. En este sentido, no queremos dejar de citar el número monográfico dedicado por la Revista de Historia Moderna de la Universidad de Alicante a la "Agricultura, riesgos naturales y crisis en la España Moderna", del año 2005.

${ }^{15} \mathrm{El}$ autor además de especificar la especie que ataca a la agricultura espańola (el Dociostaurus maroccanus), localiza como áreas de reproducción endémicas: el Valle de la Serena (Badajoz), Valle de Alcudia (Ciudad Real) y los Monegros (Aragón). Vid. Julián Montemayor, "Les invasions de sauterelles dans l'Espagne intérieure" en B. Bennassar, ed., Les catastrophes naturelles dans l'Europe medievale et moderne, Toulouse, Presses Universitaires du Mirail, 1996, 261-269.

${ }^{16}$ Agustín Rubio Vela, "Presencia de la langosta. Plagas en la Valencia Bajomedieval”, Saitabi, núm. 47, 1997, 269-288; Armando Alberola Romá, Catástrofe, economía y acción política en la Valencia del siglo XVIII, Valencia, Ed. Alfons el Magnànim, 1999, y "Procesiones, rogativas, conjuros y exorcismos: El campo valenciano ante la plaga de langosta de 1756", Revista de Historia Moderna. Anales de la Universidad de Alicante, núm. 21, 2003, 383-410. 
zona atlántica también padecerá el mal en su latitud más suroccidental: las islas Canarias, donde su estado de eterna primavera y la cercanía a la costa africana la convierte en blanco del azote en varias ocasiones, a lo largo de la modernidad, según testimonia Díaz Hernández. ${ }^{17}$ En Andalucía, merecen un significativo reconocimiento las obras conjuntas, y a la vez coetáneas, de López Cordero y Aponte Marín, para Jaén, y las de Vázquez Lesmes y Santiago Álvarez en Córdoba, cuyos modelos de estudio y relevantes resultados trascienden la realidad experimentada fuera de la fronteras jienense y cordobesa, respectivamente, sin faltar noticias de otras provincias andaluzas. ${ }^{18} \mathrm{La}$ relación de aportaciones científicas sigue aumentando en la actualidad, y será necesaria una revisión conjunta y cómputo de estudios locales para poder confeccionar un mapa completo de las plagas padecidas en suelo hispánico a lo largo del Antiguo Régimen. ${ }^{19}$

\section{ANTEQUERA Y LA MALDiCión DE LOS INFECTOS ACRÍDIDOS}

Antequera, localizada en el corazón geográfico del sur peninsular ha desempeńado a lo largo de la historia un papel destacado como cruce de caminos entre la Baja y la Alta Andalucía, entre la costa y el interior. La exención de impuestos para realizar transacciones comerciales -la denominada "alcabala", concedida durante el largo periodo de frontera con el Islam-, la convirtió durante la Edad Moderna en lugar

${ }^{17}$ Ramón Faustino Díaz Hernández, "La langosta en Canarias durante el Antiguo Régimen”, Anuario de Estudios Atlánticos, núm. 35, 1989, 67-102.

${ }^{18}$ Juan Antonio López Cordero y Ángel Aponte Marín, Un terror sobre Jaén. Las plagas de langosta XVI-XX, Jaén, Ayuntamiento, 1993. Rafael Vázquez Lesmes y Cándido Santiago Álvarez, Las plagas de langosta en Córdoba, Córdoba, Cajasur, 1993. Aunque de menor envergadura que los estudios citados, no podemos obviar el interés de otros, como el de Rafael Marín López, "Noticias sobre una plaga de langosta en Granada en 1670 y 1671”, Actas del VII Congreso de Profesores-Investigadores. Hespérides, Motril, 1988, 245-257; Adela Tarifa Fernández, Manuel Morales Romero y Enrique García García, "La ciudad de Úbeda a comienzos del siglo XviII. La plaga de langosta de 1709", Actas del X Congreso de Profesores-Investigadores. Hespérides, Sanlúcar de Barrameda, 1991, 299-308.

${ }^{19}$ Pese a no estar centrada exclusivamente en España ni en la Edad Moderna, no podemos dejar de seńalar la reciente y seńera obra realizada, desde el ámbito científico de la entomología, por: Xavier Sistach, Bandas, enjambres y devastación. Las plagas de langosta a través de la historia, Córdoba, Almuzara, 2007. El investigador aborda, incluso, la última plaga registrada en suelo africano entre 2003 y 2005 , vaticinando con pesimismo que no será la última. 
preferente para los intercambios de todos los productos desembarcados en el puerto de Málaga. No obstante, su prosperidad económica ha descansado siempre en su rica vega y en el cultivo del cereal, hasta el punto de constituirse en el granero de toda la provincia y lugares cercanos para el abastecimiento de semilla panificable.

La bondad de sus condiciones espaciales y ambientales no libró a sus sembrados de padecer distintas amenazas, entre ellas los gorrione $^{20} \mathrm{y}$, muy especialmente, la langosta. Si nos centramos en el periodo del Antiguo Régimen, varios son los momentos críticos vividos a causa de este último peligro: los meses de primavera-verano de los años 1585, 1619-1620, 1657 y 1756-1757.

Analizar individualmente, por orden cronológico, estos episodios resulta inútil pues, en muchos casos, sería redundar en las mismas estrategias para librarse del dañino insecto, pero sobre todo difícil, pues el volumen de información conservada es dispar según la fecha que se trate. Este hecho justifica la focalización de nuestro interés en los periodos donde la virulencia del fenómeno fue especialmente dramática, con un equitativo reflejo en las fuentes disponibles, de cara a profundizar en los hechos. Para la incidencia del bienio 1619-1620, contamos con unos interesantes expedientes, conservados en la Sección de Calamidades del Archivo Histórico Municipal de Antequera, sobre los elevados gastos acarreados por la extinción de la langosta en distintos partidos del término antequerano. ${ }^{21}$ Las nutridas noticias ofrecidas por estos manuscritos abarcan desde las cantidades de saltón recogido durante la campańa, número y salario de los peones encargados de su captura, métodos para la destrucción del insecto, hasta la distribución del gasto de dichas

${ }^{20}$ Estas pequeñas aves causaban, por lo habitual, daños en las sementeras, aunque en determinados años de superpoblación la amenaza era tan fiera como la de la langosta. En febrero de 1672, un bando municipal del concejo antequerano ordena a todos los varones de la ciudad presentar ante el escribano de cabildo doce cabezas de gorriones para llevar un control del exterminio, bajo pena de doscientos maravedíes por incumplimiento. Vid. Milagros León Vegas, Dos siglos de calamidades públicas en Antequera. Crisis epidémicas y desastres naturales (1599-1804), Antequera, Ayuntamiento, 2007, 268-269.

${ }^{21}$ Dicho fondo ha sido analizado detalladamente por Milagros León Vegas, "Una simiente devastadora del agro antequerano: la plaga de langosta de 1620", Revista de Historia Moderna. Anales de la Universidad de Alicante, núm. 23, 2005, 285-305. 
operaciones a través de la recaudación de dinero entre los moradores y residentes en la ciudad. La constitución dentro del concejo de juntas "extraordinarias", cuando se padecía una hecatombe en la ciudad -ya fuera vírica, tipo peste bubónica, o de otra naturaleza, como el desastre agrario-, tenía como fin la efectividad, dada la frecuencia de sus reuniones, las cuales quedaban registradas en documentación municipal, pero segregadas de las actas ordinarias del cabildo civil. ${ }^{22}$ En el embate de 1756, aparece la denominación de "junta de la langosta" y en ella hallamos siempre al corregidor, acompańado de un mínimo de tres o cuatro regidores, a los cuales se sumarían, por invitación del concejo, miembros del cabildo eclesiástico. ${ }^{23}$ Lamentablemente, la existencia de estas fuentes para la decimoséptima centuria no se confirma en la siguiente. De hecho, para evidenciar la tremenda plaga de 1755 , la segunda en volumen de datos recopilados, partimos de las breves referencias contenidas en los libros de actas capitulares de las corporaciones secular y eclesiástica de Antequera. También podemos leer alguna lacónica reseña, a modo de efeméride, en crónicas locales. El presbítero Cristóbal Fernández en su "Historia de Antequera", impresa en 1845, anota lo siguiente: "Una horrible y espesa nube de langosta cayó sobre los campos de Antequera el año de 1756, plaga que no habían experimentado en más de un siglo, según testificaban los ancianos y la tradición, y después jamás se ha visto en el país". ${ }^{24}$

22 Estas reuniones extraordinarias con representantes del gobierno local se mantienen, incluso, en las plagas registradas en Espańa durante el siglo xIx, si bien, en este tiempo, la representación se amplía a particulares propietarios de tierras. Así lo indica el abogado de los tribunales de la nación: Isidro Benito Aguado, Vida histórica de la Langosta y manual de ayuntamientos para la extinción de este insecto, $3^{\mathrm{a}}$ ed., Madrid, Imprenta de D. Norberto Llorenci, 1842, 42: "En 4 de mayo de 1824 se mandó formar juntas en todos los pueblos compuestas de algunos particulares, síndico general y vecinos labradores, presididas por la primera autoridad, para entender de la extinción exclusivamente. Esta corporación se ha formado siempre que ha ocurrido la langosta”.

${ }^{23}$ (A)rchivo (H)istórico (M) unicipal de (A)ntequera. Fondo Municipal. Actas Capitulares, libro núm. 1749. Sesión del 22 de abril de 1758. En dicho cabildo se invita al prepósito y al canónigo de la Colegiata para que se unan a la citada Junta extraordinaria.

${ }^{24}$ Cristóbal Fernández, Historia de Antequera desde su fundación hasta el año de 1800, Imprenta del Comercio, Málaga, 1842, 298. 
De cualquier manera, los métodos utilizados en el siglo XvII para erradicar esta calamidad -los cuales serán descritos de forma pormenorizada en el siguiente apartado-, son extrapolables a toda la Edad Moderna, lo cual no impide puntualizar, a lo largo de nuestro discurso, hechos diferenciales y destacados, sobre todo desde el ritual. Por ejemplo, el caso de la visita de la cabeza de San Gregorio Ostiense a la ciudad, en 1757, inserta dentro de un proyecto religioso, general y nacional para aniquilar al insaciable saltón, acorde con las medidas centralizadoras adoptadas por el nuevo gobierno borbónico.

\section{"A Dios rogando y con el mazo dando": Entre lo mágico y lo humano}

Cuando irrumpe la noticia de la existencia de langosta en los cultivos o parajes próximos, estamos ante un mal consumado. Rara vez se trata de prevenciones, sino de actuaciones desesperadas ante un desastre irrefrenable de extraordinarias dimensiones. Las limitaciones técnicas del hombre de la Edad Moderna para enfrentar una masa de insectos capaz de elevarse y devorar todo a su paso, explica las numerosas imprecaciones a la intervención divina, la prácticas de exorcismos para librarse de una maldición demoníaca o el recurso a distintos santos, cuya constatada efectividad contra el cigarrón fuera garante de un nuevo milagro. Menor fe y crédito, pero más practicidad, presentan las tareas de rompimientos de tierras o la recolección de larvas y cañutillo, a través de cuadrillas de jornaleros, pese a llevar aparejadas una nueva calamidad: el endeudamiento vecinal.

\section{Prácticas religiosas}

Antequera no escapa a la realidad generalizada en la Europa occidental de la Edad Moderna. Una sociedad cristiana profundamente creyente imbuida, a su vez, en concepciones mágicas y supersticiosas como única vía para explicar el carácter extraordinario de los fenómenos naturales, sobre los cuales no podía ejercer ningún tipo de control. Según lo referido, no es de extrañar el marcado sentido religioso de las primeras noticias sobre la presencia de cigarrones.

Entre los usos devotos puestos en marcha ante una catástrofe de esta magnitud, podemos distinguir los aplicados en los momentos 
previos a la eclosión de la espesa nube de insectos y los más desesperados, a partir del recrudecimiento de la situación, ante la ineficacia o limitación de los medios humanos empleados.

Dentro de la primera fase, menos letal pero antesala de una adversidad mayor, encontramos el recurso a la oración pública. Si las peticiones insertas en el rezo personal podían gozar de la respuesta positiva del "cielo", la fuerza de la rogativa conjunta de los vecinos, añadía más posibilidades de éxito. Así lo evidencia la solicitación del concejo antequerano a los canónigos de la Iglesia Colegial, del 24 de abril de 1619 , para organizar preces comunes y populosas..$^{25} \mathrm{La}$ presta reacción se concreta en dos procesiones del Santísimo, una al día siguiente, festividad de San Marcos, y la otra durante la jornada dominical, concurriendo en ellas los representantes de ambos cabildos, civil y eclesiástico. ${ }^{26} \mathrm{~A}$ estos desfiles "generales", se sumarían las letanías celebradas en cada parroquia, junto a la consagración de las misas oficiadas el jueves en la Colegiata de Santa María, y las plegarias continuas pronunciadas por los clérigos de todas las iglesias conventuales de la ciudad. ${ }^{27}$

La importancia de la rectitud moral para lograr el beneplácito de Dios se evidencia, durante la primavera de 1619, en la insistente recomendación del prelado a la corporación concejil para asistir y comulgar en el culto solemnizado los domingos en la Colegial, con el fin de servir de ejemplo al resto de fieles. ${ }^{28}$

Las advocaciones marianas van a tener también un protagonismo destacado en los ceremoniales petitorios. Para contener la amenaza, de mayo de 1657, se procesiona a la patrona, la Virgen de los Remedios ${ }^{29}$ y a Nuestra Señora de la Esperanza; esta última tras haber celebrado en su honor un novenario en el templo mayor de la

${ }^{25}$ AHMA, Fondo de la Real Colegiata de Santa María. Actas Capitulares, libro núm. 5.

${ }^{26}$ Un ejemplo sobre el cuidado observado a lo largo de estas manifestaciones piadosas lo ofrece: José Sierra Pérez, "La música en el Monasterio de Guadalupe (algunas reflexiones en torno a la solemne procesión de la rogativa por la langosta en 1755)", Arts e Sapientia, núm. 0, 1999, 83-102.

${ }^{27}$ AHMA, Fondo de la Real Colegiata de Santa María. Actas Capitulares, libro núm. 5. Sesión del 2 de mayo de 1619.

${ }^{28}$ Ibidem. Sesión del 18 de mayo de 1619.

${ }^{29} \mathrm{Ibidem}$, libro núm. 11. Sesión del 5 de mayo de 1657. 
urbe. ${ }^{30}$ El destino de la comitiva siempre va a ser el Cerro de la VeraCruz, un promontorio natural donde se localiza una ermita del mismo nombre y desde cual se divisaba todo el campo antequerano. ${ }^{31}$

Una vez la langosta adquiere la dimensión de plaga, es decir, cuando llega a estado adulto y es capaz de volar aglutinada en una espesa y negruzca masa flotante, el recurso piadoso adquiere un matiz mágico. El saltón gregario no es más que la materialización física del demonio, ante el cual sólo cabe el exorcismo. ${ }^{32}$ Sermones, aspersiones con agua bendita, rituales en los cuales se destruye una pequeña porción de langosta, simbolizando el fin del maleficio, van a ser habituales.

En Antequera, las exhortaciones para contener el efecto pernicioso de la plaga correrán a cargo de miembros de órdenes religiosas masculinas afincadas en la localidad como, por ejemplo, los capuchinos. Éstos son los primeros en encargarse de la conjura del mal en la primavera de 1619 y quienes, con las siguientes palabras, verifican la impotencia del hombre ante un fenómeno que excedía sus posibilidades técnicas y humanas: "[...] ai tanta que le pareze y parezió a los dichos padres es imposible poderse acavar y consumir con medios humanos, y lo mismo han informado a este cavildo algunos capitulares que la an visto y el mejor remedio que visto se puede tener es ir continuando con la oración y devociones que esta çiudad a comenzado". ${ }^{33}$

De esta forma, durante la intensa campaña de extinción promovida en la primavera de 1620, vamos a comprobar la acción combinada de miembros de congregaciones distintas, como los carmelitas

${ }^{30}$ Ibidem. Sesión del 12 de mayo de 1657.

${ }^{31}$ Para adentrarse en el significado religioso y urbano de este paraje, consúltese: $\mathrm{Mi}$ lagros León Vegas, "Un enclave sacralizado en la urbe antequerana. La ermita, beaterio y hospital de la Vera-Cruz (siglos XVI-XVIII)", Baetica, núm. 28, 2006, 433-456.

${ }^{32}$ Verdaderamente, las limitaciones científico-técnicas del momento convierten al recurso religioso en la más eficiente de las soluciones. Así lo afirma: José Rodríguez Molina, "Los 'insecticidas' en la etapa precientífica", Boletín del Instituto de Estudios Giennenses, núm. 153, 1994, 685-743. Una interesante aproximación sobre las prácticas exorcistas, desde la perspectiva de la historia de las mentalidades, nos la ofrece: Martín Gelabertó Vilagran, "Tempestades y conjuros de las fueras naturales. Aspectos mágico-religiosos de la cultura en la Alta Edad Moderna", Manuscrits, núm. 9, enero 1991, 325-344.

${ }^{33}$ Aнma, Fondo Municipal. Actas Capitulares, libro núm. 1615. Sesión del 6 de mayo de 1619. Los cabildos de los días 17 y 30 del citado mes y año nos dan noticias de la realización de otros exorcismos. 
descalzos del convento de Belén, los clérigos de San Francisco y, muy particularmente, la destacada colaboración de fray Francisco de Cabrera, ${ }^{34}$ de la orden agustina, en consonancia con la popularidad alcanzada por sus frailes en lo tocante a este tipo de ceremonias, máxime desde los milagros atribuidos a San Agustín en las tragedias sucedidas en España durante el medievo. ${ }^{35}$ De todas formas, en el caso concreto de Antequera, el patrono elegido en la lucha contra la langosta fue San Hugolino, ${ }^{36}$ del cual se manda costear una pintura para colocarla en las casas capitulares. ${ }^{37}$

${ }^{34}$ La figura de este agustino traspasa los límites de su actuación en los hechos descritos, al ser el autor de una de las más memoradas historias de nuestra localidad, titulada: Descripción de la fundación, antigüedad, lustre y grandezas de la muy noble ciudad de Antequera, manuscrito, primera mitad del siglo XvII. Aunque este religioso no dejó testimonios escritos de sus prácticas exorcistas, ni sobre la evolución de la plaga en concreto, muchos sí dieron noticia de los progresos humanos y divinos contra el mal, como el cura encargado de la conjura de la langosta en 1780 en villa de Malpartida, en Plasencia (Cuenca). Nos referimos a Juan Antonio Zepeda y Vivero y a su obra: Agricultura metódica, acomodada a la práctica del país, con varias noticias acerca de la naturaleza, propagación y extinción de la langosta, Madrid, oficina de don Benito Cano, 1791, 158-170. En ella aporta algunos datos interesantes, sobre todo desde el punto de vista climatológico, indicando la sequedad del ańo precedente a la plaga (1780) y las heladas registradas en el siguiente a la catástrofe (1782). Precisamente, el autor señala las bajas temperaturas como freno natural a la reproducción del dańino insecto.

${ }^{35}$ El poder atribuido a San Agustín data, concretamente, de la catástrofe acaecida en Toledo en 1268, cuando ante las súplicas de sus hijos, "Díos envía a San Agustín”, quien con su báculo arrojó toda la langosta al río Tajo. Vid. Rafael Vázquez Lesmes, y Cándido Santiago Álvarez, op. cit., p. 132.

${ }^{36}$ Ahma, Fondo Municipal. Actas Capitulares, libro núm. 1614. Sesión del 8 de mayo de 1620 .

${ }^{37}$ Ibidem. Sesión del 21 de agosto de 1620. Junto a este santo se ordena también la representación del resto de titulares de la ciudad: san Felipe, Santiago, Francisco de Paula y san Mauricio. No obstante, los patronos elegidos como protectores ante esta catástrofe varían según la época que se trate. Por ejemplo, el milagro de la Virgen de la Esperanza, durante una de las primaveras de la década de los ochenta del siglo XviI, es relatado por: Francisco Barrero Baquerizo, Historia de Antequera, manuscrito, 1732, fol. 250r: "juntas las parroquias, y comunidades tomaron en andas a la Virgen de la Esperanza, y fueron en procesión hasta la hermita de la Vera Crus, que está en el serro así llamado. Y puesta la Santa Virgen mirando la bega, y campo enpesó el clero, muy devoto y de rodillas, a aclamar y rogar según las suplicas tiene la Iglesia, y oiéndolos la Virgen pura, vieron en aquel instante, que maravilla!, levantarse del suelo la fiera plaga de langosta, y volver a tapar a el sol sus grandísimos exércitos, y nublados, y se fue a perecer toda, a grandes voladas, a el río de Guadajos, que está en medio de la Bega”. Así mismo, el 2 de mayo de 1732, los propietarios de viñas y heredades instituyen una fiesta anual, 
Conocemos, por las continuas referencias documentales, de la asiduidad a las invocaciones al "maligno" representado por este diminuto animal, auque no hallamos excesivos detalles sobre cómo se desarrollaba el ritual, ni el discurso empleado durante el mismo. ${ }^{38} \mathrm{El}$ famoso padre Cabrera, ataviado con estola, solía protagonizar los actos más enfáticos empleando agua bendita mientras, con su oración, intentaba bendecir un campo sembrado de corrupta simiente, donde sólo descollaban las cruces clavadas en una tierra, cuya esterilidad aumentaba por momentos. ${ }^{39}$ Destacada hubo de ser también la intervención de los franciscanos, a quienes, en cierta ocasión, se les gratificó con una limosna de doscientos reales, con motivo de la procesión organizada por dicha comunidad para acompañar al exorcista fray Francisco de Bustos hasta el citado cerro de la Vera

en la iglesia de la Caridad, a la devoción de San Gines de la Jara, como protector contra la langosta. Vid. Aнma, Fondo Notarial. Escribanía de Esteban de Rojas Ballartas, leg. 448, fols. $21 \mathrm{r}-22 \mathrm{r}$.

${ }^{38}$ La conceptualización demoníaca y malvada de este insecto es perceptible en el curioso proceso judicial emprendido contra el mismo, en 1650, por el bachiller Manuel Delgado, cura de la aldea de Párraces (Segovia). Las langostas son declaradas culpables y condenadas al destierro por los estragos agrícolas causados en los últimos cuatro ańos, con pena de excomunión, al estar incitadas por el conjuro de un espíritu maligno. El insólito caso es relatado, con todo lujo de detalles, por: Julián Zarco Cuevas, "Pleito que se puso en la Abadía de Párraces para el exterminio de la langosta", Boletín de la Real Academia de la Historia, tomo 100, Madrid, 1932, 313-348 y por Francisco Tomás y Valiente, "Delincuentes y pecadores", en Vv. AA., Sexo barroco y otras transgresiones premodernas, Alianza Editorial, Madrid, 1990, 11-31. Por otra parte, para un mejor conocimiento de estas prácticas consúltese: Juan Antonio López Cordero, "Magia, superstición y religión en el agro jiennese. Las plagas de langosta”, en J. La Torre García y J.C. Sánchez León, eds., Magia y religión en la historia, Jaén, uned, 1997, 101-121. Así mismo, contamos con descripciones sobre los rituales de exorcismo cohetanos a las plagas; por ejemplo, el impreso depositado en la Bilioteca del Hospital Real de Granada con el título: Principios para aplacar la ira de Dios, medios para solicitar su misericordia, por la interseción de María Santísima, San Gregorio Ostiense, y otros santos, con el fin de lograr con exorcismos la extinción de las plagas de langosta..., Granada, 1757; o la obra del escribano del Santo Oficio, Bartolomé Jiménez Patón, Discurso de la langosta, que en el tiempo presente aflige, y para el venidero amenaza, Baeza, Pedro de la Cuesta Impresor, 1619, conservada en la Biblioteca Nacional de Madrid.

${ }^{39}$ Este exorcismo tuvo lugar el 7 de mayo de 1620: "y el dicho padre fray Francisco de Cabrera conjuró la dicha langosta, e para ello traía una estola puesta, e puso cruzes en el partido de la Deleitosa y echo agua que dixo quera bendita y hiço otras ceremonias". AHMA, Fondo Municipal. Sección Calamidades, leg. 365. Cuadernillo titulado: "Quenta que tomó Joan Moreno Çermeño de los gastos de la langosta. Año 1620”, sin foliar. 
Cruz, desde cuya loma, muy probablemente, se vislumbraría un horizonte desolador. ${ }^{40}$

El aviso a la clerecía local no excluía la posibilidad de requerir sacerdotes de otras poblaciones, reputados por la efectividad de sus invocaciones. Así, a comienzos de 1620 se demandó al padre provincial de los franciscanos de Granada la colaboración de un conventual de Baeza, el aludido fray Francisco de Bustos. ${ }^{41}$ Éste, escoltado por los regidores y el escribano encargado de dar fe de lo acontecido, lanzó su sortilegio, entre el 10 al 12 de mayo del mismo año, en los partidos de la Deleitosa, Pinillos, Casarejo y Monte de los Frailes. Así mismo, proporcionó al concejo una normativa escrita a seguir en estas situaciones tan adversas, la cual, desgraciadamente, no ha llegado a conservarse. ${ }^{42}$

En la plaga de 1657, tenemos constancia de la visita de otro reputado exorcista: el cura Juan Carrasco del municipio de las Algamitas, en la provincia y diócesis de Sevilla. Su estancia, prolongada todo el mes de mayo, surtió el efecto deseado, pues el concejo reconoce la acción de la misericordia divina, la disminución del saltón y un merecido pago al sacerdote hispalense por los servicios prestados. ${ }^{43}$

Justo un siglo después, en 1756, Antequera revivirá el desastre de la langosta. La uniformidad de estrategias empleadas para combatir

${ }^{40} \mathrm{El} 15$ de mayo de 1620 se despacharon las cantidades para pagar al convento por este servicio. AHMA, Fondo Municipal. Sección Calamidades, leg. 365. Expediente encabezado como: "Quenta que se tomó al regidor Bartolomé de Rivera del gasto de la matanza de la langosta en 14 de septiembre de 1620 ", s/f.

${ }^{41} \mathrm{Si}$ bien, las diligencias para conseguir las prestaciones de dicho fraile comenzaron en el cabildo del 14 de febrero de 1620, fray Francisco de Bustos no acudió hasta el mes de mayo. AHмa, Fondo Municipal. Actas Capitulares, libro núm. 1615. Sesión del 8 de mayo de 1619.

42 "Y el dicho padre frai Francisco de Bustos a benido a esta ciudad a cumplir con lo que el padre provincial le tiene mandado y ordenado çerca de los dichos exorcismos. El qual a entregado un memorial de las cosas que la ciudad a de haçer invocando el ausilio divino para que más bien suceda, que dava y dio quenta a la çiudad y exhibió la memoria”. AHмa, Fondo Municipal. Actas Capitulares, libro núm. 1615. Sesión del 8 de mayo de 1620. No obstante, dichas recomendaciones nunca llegaron a anotarse, a pesar de estar reservadas dos hojas del citado libro de cabildos, que aún hoy siguen en blanco.

${ }^{43}$ Aнma, Fondo Municipal. Actas Capitulares, libro núm. 1646. Sesión del 25 de mayo de 1657. 
al animalejo durante el gobierno borbónico de la decimoctava centuria es apreciable también desde el ámbito religioso, pues la ciudad va a incluirse en la nutrida lista de poblaciones asistidas por las reliquias de San Gregorio Ostiense.

Este Santo se labró en vida la fama de abogado contra el pulgón al defender, mediante prodigiosos sermones, los campos de su diócesis navarra, hasta que falleció en $1044 .{ }^{44}$ Desde el siglo XII, su cabeza se venera en el santuario navarro de Soslada, meca de peregrinación de toda España en la Edad Moderna, al objeto de recoger el agua bendita pasada por el interior de sus huesos, único antídoto constatado para evitar la llegada del insecto o motivar su emigración a sitios alejados de los cultivos del hombre. ${ }^{45}$ Estamos ante el remedio espiritual más prestigioso contra las amenazas sufridas por el agro español a lo largo del Antiguo Régimen, colofón de una serie de rituales de menor dimensión mágica. ${ }^{46}$

En consecuencia, en los mapas confeccionados por historiadores sobre la peregrinación del cráneo del que fuera obispo de Ostia, a

${ }^{44}$ Uno de los relatos más tempranos donde encontramos la historia que dio origen a la devoción de San Gregorio es la escrita por el canónigo de la Catedral de Salamanca: Pedro Ciruelo, Tratado en el qual se repruevan todas las supersticiones y hechizos..., Barcelona, Sebastián Carmellas, 1628, 56-57. Por otra parte, entre las revisiones más recientes sobre el asunto, hallamos la realizada por: Roldán Jimeno Aranguren, "Configuración de una identidad hagiográfica popular: la leyenda de San Gregorio Ostiense”, Zainak, núm. 22, 2003, 89-101.

${ }^{45}$ Consúltese: Juan José Barragán Landau, "Las plagas del campo español y la devoción a San Gregorio Ostiense", Cuadernos de etnología y etnografía de Navarra, núm. 29, 1978, 273-297; Ángel Aponte Marín, "Conjuros y rogativas contra las plagas de langosta en Jaén (1670-1672)”, en C. Álvarez Santaló, M.a J. Buxó Rey y S. Rodríguez Becerra, coords., La religiosidad popular II. Vida y muerte: la imaginación religiosa, Barcelona, Anthropos, 1989, 556-558 y Javier Blasco-Zumeta, "Breve nota sobre langosta y superstición hasta la ilustración del siglo Xvin", Boletín de la Sociedad Entomológica Aragonesa, núm. 20, 1997, 363-365.

${ }^{46}$ La distribución del agua bendita de San Gregorio estuvo muy regulada, exigiéndose a los comisionados procedentes de todos los lugares de la Península, una cédula firmada por sus autoridades civiles o eclesiásticas, explicando las razones para retirar una porción de tan prodigioso líquido. Vid. Juan Cosme Sanz Larroca, "Aguas milagrosas contra plagas en la Espańa del siglo xviı", Tiempos Modernos (revista electrónica), núm. 20, 2010/11 y Teófanes Egido, "Los otros usos del agua: el agua bendita", en Marcos Martín, Alberto, coord., Agua y sociedad en la época moderna, Universidad, Valladolid, 2009, 121-131. 
través de las diversas regiones españolas afectadas por canutillo, es necesario incluir a Antequera y, con ella, al centro geográfico de Andalucía.

El primer indicador de la inminente participación de una localidad en este místico evento era el acuse de una Real Provisión de Fernando VI, fechada en Madrid, el 14 de octubre de 1756, anunciando la pronta llegada de los vestigios de San Gregorio. ${ }^{47}$ Será en la sesión del 15 de enero de 1757, cuando el concejo antequerano reciba la buena nueva. En dicha notificación oficial se indica el trayecto que recorrerán los restos del santo, a través de las provincias afectadas, desde su primer periplo de salida Pamplona-Teruel hacia Valencia, Segorbe, Orihuela, Murcia, Guadix, Granada, Jaén, Málaga, Córdoba, Sevilla, Extremadura y La Mancha. Los cuatro miembros de la cofradía encargada de este traslado, tres eclesiásticos y uno secular, viajarían en una carroza financiada por la Corona, mientras los gastos de manutención de los cofrades debían correr a cargo de los propios y arbitrios de las ciudades donde hicieran alto. El tiempo de estancia no superaría los dos días, tiempo suficiente para realizar la conjura de la langosta y dejar una pequeña porción de agua bendita en cada lugar, junto a los formularios impresos con rezos para poderlos distribuir fácilmente por los pueblos comarcanos.

La ansiada visita de las reliquias de San Gregorio Ostiense a Antequera tuvo lugar el martes 18 de enero de $1757 .{ }^{48}$ En torno a las seis de la tarde, una representación de los cabildos civil y eclesiástico se adelantó en carruajes a las afueras de la ciudad por el camino de Granada para recibir a la comitiva peregrinante y guiarla a la iglesia colegial de San Sebastián, lugar prevenido con una recepción digna de tan insigne concurrencia. Una vez en las puertas del templo, mientras repicaban las campanas y el coro entonaba el Te Deum, el

\footnotetext{
${ }^{47}$ AHMA, Fondo Municipal. Actas Capitulares, libro núm. 1748. Al final de la sesión se transcribe íntegramente el real mandato.

${ }^{48}$ Ahma, Fondo de la Real Colegiata de Santa María. Actas Capitulares, libro núm. 23. Sesión del 18 de enero de 1757 . Justo el año anterior, durante la trágica plaga de 1756, las reliquias de San Gregorio Ostiense visitaron numerosas ciudades del sur peninsular, entre ellas Málaga. Así lo señala: Andrés Sarriá Muñoz, Religiosidady política. Celebraciones públicas en la Málaga del siglo XVIII, Málaga, Gráficas San Pancracio, 1996, 123-124.
} 
preste tomó la reliquia y precedido por las autoridades convocadas, todas con cirios encendidos, desfilaron en procesión hasta el altar mayor, depositando la cabeza del patrono en un reliquiario, mientras se prestó veneración y una solemne oratoria.

Al día siguiente, estaba prevista una procesión al cerro de la Vera Cruz, con oficio de una misa al aire libre y bendición de los labrantíos, aprovechando la altitud de ese montículo natural. Sin embargo, la intensa lluvia caída durante la noche y a lo largo de la mañana impidió tal ofrenda, la cual tuvo lugar en la misma iglesia colegial, presidida por el santo cráneo, ante todo el pueblo de Antequera. Una vez concluida la oración común, se inició el ritual del exorcismo en la anexa plaza de San Sebastián, donde se sacó la reliquia y en su presencia el preste pronunció las jaculatorias oportunas. De forma ordenada, los capitulares de los cabildos civil y eclesiástico volvieron a formar para retornar la cabeza de San Gregorio al altar mayor, mientras el coro concluía sus cantos, dando así por finalizado el antídoto religioso contra el mal.

Sin embargo, el prestigioso suceso no reportó los efectos deseados. El canutillo anidado en los campos en 1756, revivió y en marzo del año siguiente los estragos eran evidentes. ${ }^{49}$ Fue entonces el momento oportuno para ejecutar los rituales aplazados, a principio de año, por la adversa climatología. Así, a las cinco de la tarde del 3 de marzo de 1757, salió en procesión de la colegiata un copioso cortejo formado por representantes de las corporaciones civil y eclesiástica, así como curas párrocos, delegados de cada una de las órdenes regulares de la ciudad y de hermandades seculares. Enfilaron por calle Encarnación y Carrera, y tras subir la cuesta de Archidona llegaron a la ermita del cerro de la Vera Cruz. Allí mismo, al descubierto, junto a una gran cruz de madera, se realizó la conjura: una pequeña cantidad de langosta, apilada en una caja, fue depositada en un hoyo en el suelo para después ser quemada, a la vez que se pronunciaban los conjuros y la consagración del agro circundante. La vuelta se realizó por calle de la Cruz, plazuela de la Cruz Blanca, Lucena y Estepa,

${ }^{49}$ AHMA, Fondo de la Real Colegiata de Santa María. Actas Capitulares, libro núm. 23. Sesión del 3 de marzo de 1757. 
hasta el templo de San Sebastián, mientras eran entonados los salmos propios de la época, previos a la asunción de la virgen en el mes de mayo. Precisamente, en este tiempo volvió a repetirse el desfile, esta vez conduciendo a la imagen de Nuestra Señora de la Antigua, hasta el recurrente cerro, para invocar la misericordia divina..$^{50}$

No vamos a relatar los innumerables "actos de gracias" oficiados tras el repliegue de la langosta, aunque siempre estuvieron presentes como cierre de los episodios más duros vividos por los antequeranos.

Las crisis económicas acarreadas por catástrofes - de índole natural, en la actualidad, sobrenatural para el hombre de la Edad Moderna-, van a estar inauguradas, acompañadas y clausuradas por sendas ceremonias religiosas, las cuales constituyen indicadores inequívocos de las limitaciones científico-técnicas de la época y de la mentalidad del momento, marcada por un justificado miedo a un entorno hostil, sentimiento sólo contrarrestado con el arma de la superstición y el anhelo a la intervención de una fuerza redentora.

\section{Medios humanos: roturaciones y captura del insecto}

Pese a la incesante apelación de la intercesión divina y a las afanadas imprecaciones contra el demonio materializado en artrópodo, la documentación consultada evidencia una actuación humana en cierta medida práctica y racional -si tenemos en cuenta el periodo histórico-, dirigida y coordinada, en todo momento, por las autoridades civiles. ${ }^{51}$

La destrucción física del pequeño animal va a ser uno de los desvelos de las poblaciones afectadas y Antequera no es una excepción. Tampoco van a ser diferentes los métodos empleados, siendo el más recurrente, cuando la langosta se encuentra en la primera fase -esto

${ }^{50}$ Ibidem. Sesión del 7 de mayo de 1757.

${ }^{51}$ Aunque puntualizaremos siempre la cronología, queremos advertir, desde el principio del apartado, la casi exclusiva consulta de documentación relativa a las campañas de extinción de langosta de 1619-1620, por ser la única conservada fuera de las ordinarias actas capitulares del concejo. No obstante, la riqueza de informaciones y la susceptibilidad de extrapolarlas a otros años, marcados también por el desastre del saltón, convierte al legajo núm. 365, del fondo municipal "Calamidades", en una importante fuente de análisis y de continua referencia. 
es, en forma de huevo o de larva-, la roturación de tierras. Éste se perfila, a lo largo de la Edad Moderna, como la fórmula más eficaz en cuanto a exterminio. El mismo Bowles recomienda esta opción para erradicar el problema, por su validez y bajo coste, con las siguientes palabras "mejor sería aniquilar esta horrible plaga en las dehesas de donde se origina, y donde, poca o mucha siempre existe, con lo que se conseguiría exterminarla de raíz" ${ }^{52}$ En consecuencia, remover los terrenos en los que las langostas habían desovado, mediante arados, suponía fragmentar las vainas donde estaban protegidas en su estado embrionario, erradicando el problema antes de convertirse en plaga. La Instrucción de 1755, aconseja, además del uso del simple rastrillo, el del arado con "orejeras baxas, con dos rejas juntas y los surcos unidos" ${ }^{53}$ La idea era desenterrar en profundidad el canuto y, al romperlo, exponer su contenido a la sequedad del ambiente o bien presentarlo de suculento festín al ganado, a los cerdos e incluso a las aves de corral. En suma, la táctica buscaba combatir al insecto en su fase más vulnerable.

Aunque la eficacia del método venía avalada por todos los tratados y normativas publicadas en España, entre los siglos XVII y XVIII, existía un deseo encubierto de los agricultores por arar las dehesas pues, no sólo podían ser incorporadas a los labrantíos, una vez desalojada de insectos, sino que se trataba de una inmensa superficie fértil abonada por el pastoreo. A veces, la langosta fue vista por los agricultores como la mejor excusa para ampliar el área cultivada en detrimento de la ganadería. La monarquía hispánica, siempre proclive a favorecer a este último sector -si bien permite y recomienda, previa inspección de peritos, la roturación de las zonas afectadas por el saltón-, prohíbe taxativamente su laboreo, a través de la provisión del 11 de septiembre de 1723 y la Instrucción de 1755. No obstante, lo costoso de los rompimientos acabó por convencer a la Corona para dar facultad, tanto a los concejos como a los particulares, para sembrar las extensiones desovadas por una o dos cosechas, al menos,

${ }^{52}$ Guillermo Bowles, op. cit., p. 279.

${ }^{53}$ Véase artículo v de la Instrucción de 1755. 
durante la segunda mitad del siglo xviII. ${ }^{54}$ En Antequera, los primeros intentos por rentabilizar el surcado de nuevas heredades, tanto de realengo como de propios, se concretan en arriendos, según acuerdo de la sesión capitular del 11 de agosto de 1620. El único inconveniente de la explotación agrícola de los terrenos traspasados, fue la infracción de las disposiciones vigentes por entonces -dadas por el Consejo Real, en la Provisión del 13 de mayo de 1619-, por las cuales se convenía la continuidad del pastoreo en dichas tierras, en concordancia con lo expuesto más arriba. ${ }^{55}$

Pese a todo, el arado de ingentes campos no siempre fue provechoso para la agricultura. Al menos, a corto plazo, deja secuelas en materia de producción agrícola. Particularmente perjudicados resultaban los campesinos obligados a llevar sus bueyes de un partido a otro para remover la tierra. ${ }^{56} \mathrm{~A}$ las penalidades sufridas por las largas distancias entre los términos dañados -trayectos arduos por la ausencia de tinadas, paja o cualquier hierba forrajera-, se unía el deterioro de los cultivos, al verse privados de la roturación y del abono, garantía de la productividad de los sembrados. Como consecuencia, en el cabildo celebrado por el concejo, el 19 de mayo de 1620, se prorroga la guarda de las cercas de los predios, "porque los labradores no han podido hacer sus barbechos por causa de lluvia y por el tema de la langosta". ${ }^{57}$

${ }^{54}$ Consúltese la Novisima Recopilación..., tomo II, libro viI, título XxxI, ley v y viI, citado por: Felipa Sánchez Salazar, Extensión de cultivos en España en el siglo XVIII, Madrid, Siglo Veintiuno, 1988, 41-42.

55 "por la qual os mandamos que como con ella fuéredes requerido con mucha diligencia y cuidado hagáis que en todas las partes de los términos y jurisdicción de esta ciudad, donde hubiere la dicha langosta aobada o en canutillo o nacida la maten, cojan y destruyan, sacándola de rayz, de manera que no quede simiente ninguna y hagáis que se aren y rompan qualesquier tierras, dehesas y heredades y montes de adonde así estuviere la dicha langosta, con que lo que para esta causa y para solo este efecto se rompiere y arare, por virtud de esta nuestra carta, no se pueda sembrar cosa alguna de ello, sino que quede para pasto de la manera que antes estava”. AHMA, Fondo Municipal. Sección Calamidades, leg. 365: "Autos fechos en virtud de...", s/f. En dicho expediente se incluye la provisión original.

${ }^{56}$ AHma, Fondo Municipal. Actas Capitulares, libro núm. 1615. Sesión del 14 de enero de 1620: "se pregone que todas las personas que tuvieren bueyes y arados los registren dentro de seis días por ante mí el escribano, so pena de dos myll maravedís".

${ }^{57}$ Ibidem. Sesión del 28 de febrero de 1620. 
Una vez removida la tierra y extraído el canutillo, la ingestión de los huevos por animales no va a ser el único método para acabar con ellos. También se recurrió al acopio de los mismos por braceros, con la idea de amontonarlos para, seguidamente, soterrarlos a cierta profundidad de la superficie y provocar su asfixia, o bien, quemarlos en grandes hogueras alimentadas con paja. El personal ocupado en la recogida abarcaba más allá de los agricultores damnificados, pues las cuadrillas se engrosaban con gentes sin oficio estable, trabajadores a jornal, e incluso, con individuos incluidos en las filas de los sectores sociales más marginales.

La media de vecinos ocupados en estas actividades solía ser elevada, sobre todo, cuando las calamitosas incidencias del azote se agudizaban. Durante el transcurso de las campañas de extinción de 1619-1620, el número de reclutados fluctúa, según los ritmos de actuación del insecto, encontrándonos un máximo de setecientos hombres y un mínimo de cinco. ${ }^{58}$ Del mismo modo, los honorarios que se percibían oscilaban en atención a la categoría socioprofesional del bracero. En consecuencia, si los capataces percibían cuatro reales diarios y los peones tres, los niños, mujeres y gitanos obtendrían, únicamente, uno o dos reales en el día. Esta distinción retributiva, se ajusta a un criterio de rentabilidad del esfuerzo físico y adiestramiento en las faenas del campo, aunque resulta interesante comprobar la diferenciación de la minoría conformada por los gitanos. La camarilla "calé" estaba integrada por veintidós gitanos movilizados entre los distintos cortijos del término de Antequera, donde se dedicaban a las tareas de recolección de la aceituna. Uno de ellos, Francisco Montero, comunicó al concejo, en febrero de 1620, el malestar de sus compañeros, al percibir tan sólo un real por celemín de langosta recogido, consiguiendo tras dicha representación la asignación de, al menos, dos reales diarios. Este aumento salarial resultó tan gravoso a las autoridades civiles que decidieron, desde ese mismo mes, prescindir de la intervención de los gitanos, máxime cuando intentaron cobrar el sueldo íntegro de una jornada interrumpida

${ }^{58}$ AHMA, Fondo Municipal. Sección Calamidades, leg. 365. Cuaderno de la "Quenta que tomó Joan Moreno Çermeño de los gastos de la langosta. Año 1620”, s/f. 
por intensas lluvias. Si a este hecho unimos el reproche continuo a su "eventualidad" en las labores agrícolas, constatamos la palpable desconfianza de las autoridades municipales hacia esta etnia.

La segunda fase de la extinción de la langosta coincidía con un serio empeoramiento de la situación: cuando el insecto lograba superar la fase embrionaria, desarrollando su tamańo y facultad para volar. Centrémonos en la primavera de 1620, momento de eclosión del enjambre. En las anotaciones de las fanegas de saltones recogidas hasta iniciarse el mes de mayo, se informa acerca de sus dimensiones: "y la dicha langosta es pequeña como moscas pequeñas, y la mayor como abejas" . 59 Si el cigarrón era capaz de planear aglomerado, la catástrofe estaba asegurada. Aun así, a pesar de la dificultad de su aprisionamiento, éste se intentaba bien mediante el empleo de simples y amplias sábanas, con las que se pretendían cubrir las deslizantes nubes negras formadas por la agregación de saltones, o con los famosos buitrones, una especie de red cónica hecha de lienzo y asida a un mango, de varios tamańos, acorde con la necesidad de atrapar mayor o menor cantidad de langosta y la disponibilidad o no de jornaleros suficientes. ${ }^{60}$ Aunque de diseño sencillo, el manejo del utensilio descrito requería, por sus grandes dimensiones, la ocupación de varias personas, por lo cual, no es de extrańar la designación de un responsable encargado de supervisar las tareas del contingente humano dedicado a la "caza" con red. Durante la expedición del 4 de mayo, desplegada en todos los partidos infectados Ojos, Pinillos, Monte Frailes, Casarejo y Deleitosa-, trabajaron ciento diecisiete personas proveídas con veinticinco buitrones. ${ }^{61}$

La gran movilidad del insecto nos lleva a reflexionar sobre la implicación de poblaciones cercanas en la catástrofe. Lógicamente, la facultad de la langosta para desplazarse en su fase adulta propaga-

${ }^{59}$ Ibidem.

${ }^{60}$ En las cuentas, del 14 de septiembre de 1620, consta haberse pagado al jurado Alonso de Borja 1,836 reales por una buena porción de lienzo para fabricar estos artilugios. El naturalista Bowles distingue tres tipos de buitrones, diferenciados sólo por su tamaño, especificando, en cada caso, las recomendaciones para su correcto uso.

${ }^{61}$ AHMA, Fondo Municipal. Sección Calamidades, leg. 365. Cuaderno de la "Quenta que tomó Joan Moreno Çermeño de los gastos de la langosta. Año 1620”, s/f. 
ba la amenaza de su voraz "apetito" más allá del término municipal antequerano. En consecuencia, la plaga de 1619 dejó canutillo en la mojonera encargada de señalar el deslinde con la villa de Archidona, concretamente en el Partido de los Ojos, dividido entre ambas jurisdicciones territoriales. Ante lo gravoso de la matanza, la ciudad de Antequera logró una provisión real, fechada en 10 de marzo de 1620 , por la cual se requería la contribución humana y económica de los vecinos de la localidad colindante. ${ }^{62} \mathrm{~A}$ pesar de ello, la cooperación de las autoridades archidonesas fue casi nula en esta primera fase de la operación, limitándose a surcar pequeñas extensiones de los cortijos limítrofes a la zona seńalada. El argumento esgrimido para justificar su "relajamiento", fue la poca cantidad de vainas halladas en los lugares de su competencia, parecer contrario a las informaciones recabadas entre los antequeranos. ${ }^{63}$ Efectivamente, poco después, el 25 de abril, el pequeño animal causaba estragos en el agro archidonés, momento en que el corregidor de Antequera ordena la fabricación de ocho buitrones para las tareas de captura.

Pasado algo menos de un siglo, en febrero de 1709, se invierten los papeles y es Archidona la que pide ayuda, al estar sus agros repletos de saltón. Antequera decide colaborar con este municipio antes que con Loja, el cual también solicita auxilio, simplemente por cuestiones de cercanía geográfica. ${ }^{64} \mathrm{La}$ financiación de rogativas a las imágenes más queridas, procesiones, exorcismos... y envíos de cuadrillas de hombres con pertrechos resumen toda el apoyo intervecinal. Por suerte, la cooperación preventiva resultó útil. Antequera no sufrió el azote en la primera década del siglo XviII, aunque sí soportará el de mediados de dicha centuria, último de un ciclo secular infernal al que, desde entonces, se le pone punto y final en la localidad. En esta larga Edad Moderna, repleta de crisis agrarias y plagas de langosta, no sólo hubo carestía de cereal y hambrunas, también en-

${ }^{62}$ Ibidem.

${ }^{63}$ Ibidem: "en el dicho término de la villa de Archidona abía mucha cantidad de langosta en canutillo, y se sabe que de parte de la dicha villa no se ha hecho más diligencia que la de arar la dicha tierra, y que la langosta, sin duda, saldrá dentro de muy pocos días, calentando el tiempo, que si hubiera hecho días de sol ya ubiera salido".

${ }^{64}$ AHMA, Fondo Municipal. Actas Capitulares, libro núm. 1703. Sesiones del 16 y 19 de marzo de 1709. 
deudamiento y empobrecimiento permanente de los antequeranos, según constatamos a continuación.

\section{Coste económico de la catástrofe}

Uno de los aspectos más dramáticos de la tragedia era asumir los dispendios ocasionados para sofocarla. Cuando los campos se inundan de cigarrones, ese año se declara catastrófico. Los principales afectados eran los propietarios de los agros emponzoñados y en principio, los únicos obligados a costear la extinción, si el volumen de saltón no era excesivo. Sin embargo, si su número ponía en peligro la subsistencia del conjunto poblacional, la calamidad se eleva a la categoría de "pública", donde nadie se sentía responsable pero, a la vez, todos debían contribuir económicamente, sin excepciones. En este sentido, los eclesiásticos estaban requeridos a colaborar pese a disfrutar del privilegio de la exención general de gabelas-, según ordena el rey de Castilla, Juan I, en el temprano año de 1390. Aunque la idea era ayudar en la medida de las posibilidades de cada uno, la Corona prevé el alivio de los más necesitados perdonando, puntualmente, el pago de gravámenes ordinarios. No extraña pues, la decisión de Alfonso X-incluida, entre 1252-1284, en el Libro de las Partidas-, de eximir a los campesinos de los impuestos durante el tiempo dedicado a la consumación de langosta.

Dentro de este marco normativo, encontramos otra prueba más del interés común y de la necesidad de cooperación del conjunto vecinal en el acuerdo del Consejo de Castilla, de 1593, el cual obliga específicamente a los municipios a asumir el gasto del exterminio, utilizando el caudal generado por los bienes de propios. ${ }^{65}$ Quiñones, en su tratado del siglo XVII, es de la misma opinión, aunque si aquel fondo estaba hipotecado, no descarta la derrama entre los hacendados particulares afectados, pero también de clérigos y nobles quienes, junto a los pecheros, y conforme a sus respectivos patrimonios individuales, confirmarían, con su esfuerzo, la supremacía de la uti-

${ }^{65}$ Dicha ley es incluida en la Novísima Recopilación, tomo III, libro vII, título XXXI, ley v, p. 653. 
lidad pública sobre la particular. Las mismas disposiciones, aunque con mayor previsión, presenta la Instrucción de 1755, ya que si las arcas de propios estaban vacías, indica el uso de arbitrios. ${ }^{66}$ Sólo si se constataba una manifiesta insolvencia, el gobierno central contribuiría con dinero.

En cualquier caso, poco importaba el fondo desde el cual se adelantaba el capital, pues al final, siempre se recurría a la recaudación entre el común, bien para reponer las arcas del depósito vaciado, bien para asumir el gasto desde el comienzo.

Aunque nos interesan especialmente los siglos XVII y XVIII -pues es entonces cuando empiezan a difundirse las nociones sobre el comportamiento de este tipo de artrópodo y un decálogo de actuaciones útiles contra el mal, desde instancias superiores de gobierno-, no podemos dejar de mencionar la última gran crisis agraria causada por dicha plaga en la Antequera de la decimosexta centuria, sobre todo, por las dificultades encontradas para sufragar los dispendios ocasionados. En efecto, si a finales de abril de 1585 salta la noticia de la práctica afección de todos los términos circundantes a los principales cortijos y heredades del lugar, los pagos de los antequeranos llegan a prolongarse hasta agosto de $1587 .{ }^{67}$

Los largos periodos comprendidos entre la catástrofe y el final de la distribución del desembolso vecinal nos llevan a preguntarnos cómo se llevaba a cabo esta complicada y laboriosa recolecta de dinero. El punto de partida era el padrón de habitantes y las declaraciones de caudales de los mismos, pudiéndose efectuar tantas veces como fuere necesario hasta cubrir el monto total.

Centrándonos en la plaga de langosta padecida en Antequera durante 1619-1620, la mejor documentada hasta el momento, debemos comenzar confirmando el fuerte endeudamiento de su concejo en aquellos años. Por entonces, las arcas del ayuntamiento

${ }^{66}$ Instrucción formada, sobre la experiencia..., 1755. Capítulos xx al xxi: "Gastos y modo de repartimiento".

${ }^{67}$ AHMA, Fondo Municipal. Actas Capitulares, libro núm. 1606. En el cabildo del 25 de abril de 1585 se enumeran los terrenos afectados: Partido de los Ojos de Huecar, los eriales de la Deleitosa y Casarejo, Cerro de las Campanas, Santillán el Alto, el Almendralejo y el puntal de la sierra de Mollina. 
estaban embargadas y las sisas impuestas de cara a financiar el servicio ordinario y extraordinario, así como ciento ochenta mil ducados para la perpetuación del "privilegio de su Majestad". A comienzos de mayo de 1619, se solicita ayuda al monarca, Felipe III, o bien licencia para gestionar unos consumos cifrados en cuatro mil ducados. Ante esta grave crisis, el Consejo de Castilla no va a librar ningún tipo de subsidio al municipio, sin embargo resuelve, por una provisión del 13 de mayo de 1619, que dicha cuantía se cubra, o bien en los caudales de propios, o con la contribución económica de todos los habitantes y moradores de la ciudad, con independencia de su condición social:

os damos licencia y facultad para que los maravedís que fueren menester se gasten de los propios de esa dicha ciudad y de los lugares de su jurisdicción donde hubiere la dicha langosta, o por repartimiento entre los vecinos y moradores de ella y lugares, y vecinos forasteros que en los dichos términos tubieren vienes y rentas, ansí eclesiásticas como seglares, iglesias y monasterios, comendadores y universidades que llevaren diezmos de los frutos de las dichas heredades del dicho partido, y otras qualesquier personas de qualquier estado y condición y preeminencia que sean, teniendo respecto en el dicho repartimiento al daño que pueden tener los términos públicos y concejiles. ${ }^{68}$

En dichos términos se indica la obligatoriedad del gravamen por parte de todos los antequeranos, ya fueran terratenientes o no, e incluso de los no avecindados, ya que las carestías provocadas por la plaga en materia alimenticia incidían de forma directa sobre el conjunto poblacional. ${ }^{69}$ Las aportaciones pretendían ajustarse a la capacidad eco-

${ }^{68}$ Real Provisión dada, en Madrid, el 13 de mayo de 1619, cuya copia queda incluida en las actas de cabildo del concejo, libro núm. 1615.

${ }^{69}$ Esta medida de financiación no resulta novedosa, aplicándose allí donde la langosta hacía acto de presencia. La Biblioteca del Hospital Real de Granada custodia dos impresos muy interesantes, contemporáneos a la plaga experimentada en esta provincia durante el tercer cuarto del siglo XVII, donde se detallan los pormenores de la recaudación: Memorial a la reina enviado por la Junta de la Langosta sobre la plaga que asoló Granada en 1671 y los gastos que su extinción ocasionó, Granada, 1671, y Repartimiento que se ha hecho en esta ciudad de Granada, en ambos estados para la satisfacción de los 125.467 reales, que hazen quatro cuentos 265.878 maravedis, que se deven de los gastos hechos en la 
nómica de los inscritos en el padrón vecinal. La pauta que se seguirá en los prorrateos va a ser la empleada en Córdoba durante 1619, año en el que la langosta causó los mayores estragos en dicho agro. ${ }^{70}$ En la primera asignación -fechada el 14 de febrero de 1620-, el corregidor, Diego Flores, establece la gradación de los contribuyentes según su implicación en la catástrofe y el volumen de su hacienda. De tal forma, se cargaban más a los dueños de heredades y, entre ellos, a quienes tuvieran mayores extensiones de terreno y de mejor calidad. A continuación, irían los no propietarios, según su estado económicosocial, quedando exentos de pago los menos favorecidos, es decir, viudas, pobres y jornaleros. ${ }^{71}$ Todas estas recaudaciones se realizaban siguiendo la articulación urbana y humana conformada por las seis parroquias existentes en aquel tiempo.

A simple vista, comprobamos una contribución mayor de los feligreses de San Sebastián (18,151 maravedís), seguida por los de San Pedro (3,887 mrs), San Juan (1,260 mrs), San Isidro (537.5 mrs) y San Salvador (493 mrs). ${ }^{72}$ Este hecho no sólo se debe a la conservación de las cuentas completas relativas a San Sebastián, sino también, y muy especialmente, al fenómeno urbano experimentado por la ciudad a lo largo de la Edad Moderna. Justamente, si tras la conquista cristiana el centro político y económico de la villa se sitúa entre sus murallas, con el tiempo, esa densidad poblacional revierte hacia la zona baja o llano. En consecuencia, San Sebastián se va a situar a la cabeza del resto de parroquias, tanto desde el punto de vista demográfico como urbanístico, al estar integrada por el mayor número de

extinción de la langosta de los años passados de 1670 y 1671 y otros..., Granada, 1672.

${ }^{70}$ AHMA, Fondo Municipal. Sección Calamidades, leg. 365. Documento impreso, titulado "Reglas sobre extinguir la langosta", en el cual se incluyen copias de distintas Reales Provisiones tocantes a los repartimientos.

${ }^{71} \mathrm{Ibidem}$. Esta anotación aparece al final del repartimiento realizado entre los vecinos de la Parroquia de San Sebastián en la fecha indicada.

72 Ibidem. Las cuentas de cada parroquia aparecen individualizadas en cuadernillos distintos. Desgraciadamente, no se han conservado los registros relativos a la parroquia de Santa María, ni tampoco los realizados durante los meses de mayo y septiembre de 1620, en cada una de las restantes colaciones. Las cifras que ofrecemos son sólo aproximativas al esfuerzo económico realizado por Antequera en dicho año. Los datos pormenorizados en tablas pueden consultarse en los anexos de nuestro trabajo: Milagros León Vegas, "Una simiente devastadora...”, pp. 301-305. 
calles y zonas públicas, en relación con las demás. Pese a todo, el objetivo se mantiene, al buscar la equidad de las cargas desde el punto de vista del individuo, considerando, como ya hemos señalado, su situación económica y social. Del volumen de langosta y de sus nefastos efectos dependerá la continuidad de los repartimientos, como sucedió en Antequera, durante los difíciles meses de mayo y septiembre de 1620. Tres derramas, con una recaudación total de algo más de treinta y nueve mil maravedís, de los cuales la mayoría iban destinados a pagar las cerca de cuatro mil cuatrocientas peonadas de jornaleros, con las cuales se llegaron a recopilar más de dos mil quinientas fanegas de insectos. ${ }^{73}$

No podemos dejar de mencionar el importante papel desarrollado por el corregidor, máxima autoridad civil, en cuanto a la organización del "exterminio" -haciendo efectivas las disposiciones dictaminadas por el Consejo en esta materia-, y en las exacciones monetarias sustraídas entre el vecindario. ${ }^{74}$ Los propios miembros del cuerpo concejil, por su oficio, estaban comprometidos a colaborar en dichas prestaciones, tal y como se demuestra en un memorial inserto en los cuadernos de cuentas. Así, los veintitrés jurados y los treinta y cinco regidores colaboraron, en el importante repartimiento de febrero de 1620 , con 3,272 reales. $^{75}$

Con mayores inconvenientes va a encontrarse el concejo a la hora de imponer los tributos al cabildo de la iglesia Colegial de Antequera, obligados a participar tanto por ser propietarios de grandes extensiones de terreno, como receptores de los diezmos. En vista de esta oposición, el 16 de marzo de 1620, el municipio remite un auto al

${ }^{73}$ Consúltese la tabla núm. 3 contenida en: León Vegas, Milagros "Una simiente devastadora...”, pp. 299-300.

${ }^{74}$ Algunos ejemplos sobre la implicación de las autoridades locales en la extinción de la plaga, sobre todo siguiendo las medidas centralizadoras y generales del gobierno borbónico y la Instrucción de 1755, los encontramos en: Ramón Cózar Gutiérrez, "La administración municipal y el control de las plagas de langostas en Albacete a principios del siglo xviri”, Ensayos: Revista de la Facultad de Educación de Albacete, núm. 18, 2003, 47-60 o Jesús Manuel González Beltrán, "Respuesta política frente a las adversidades naturales en el sector agrícola durante el siglo XvIII", Revista de Historia Moderna. Anales de la Universidad de Alicante, núm. 23, 2005, 359-390.

${ }^{75}$ Véase la tabla núm. 2 contenida en: Milagros León Vegas, "Una simiente devastadora...", 299-300. 
obispo de Málaga, don Luis Fernández de Córdoba, suplicándole racione entre el estado eclesiástico los ochocientos ducados que le corresponden. Tras valorarse los gastos de extinción en un total de cinco mil ducados, apremian al prelado a cumplir lo acordado en un plazo de ocho días, por lo urgente de acabar con la langosta. Éste se niega y alude a la necesidad de conseguir licencia pontificia para ello.

Las desavenencias entre las corporaciones trascienden incluso a la Real Chancillería de Granada, donde acuden representantes de ambas partes. ${ }^{76}$ Por fin, en el cabildo celebrado en la Colegial, el 14 de mayo de 1620 , el vicario de la ciudad dio a conocer una carta del metropolitano por la cual, de "forma voluntaria", el clero contribuiría económicamente a la causa, aunque sin especificar cifras: "ordenaba tratase con este cabildo que entre los interesados, prelado, beneficiados y cabildos repartiese alguna cantidad de maravedís conforme a la necesidad y posibilidad. Y que este cabildo nombrase diputado para con el dicho vicario pagase a los que cogen langosta al precio que se coge la fanega de ella". ${ }^{77}$

Pocos días después, en la sesión del 25 de mayo, se fija la cantidad que se prorrateará en seiscientos reales, unos cincuenta y cuatro ducados y medio, suma bastante inferior a la compelida por las autoridades civiles.

El retraimiento e interposición de excusas por parte de la clerecía local es constatable incluso en la siguiente centuria. En la plaga de 1756-1757, el cabildo de la Real Colegiata de Antequera solicita al obispado de Málaga la confirmación de la contribución forzosa y, siendo así, se procurase la benévola competencia del juez secular encargado de hacerse con el dinero, para no ocasionar perjuicio alguno del estado eclesiástico. ${ }^{78}$

Ante la ingente y complicada solicitación de pagos, no extraña el recurso a capitales englobados en los depósitos de obras pías y mayorazgos. Este dinero era susceptible de ser utilizado por el concejo

${ }^{76}$ Los delegados del clero fueron elegidos en la sesión del 7 de mayo de 1620. AHMA, Fondo de la Real Colegiata de Santa María. Actas Capitulares, libro núm. 5.

77 Ibidem.

${ }^{78}$ AHMA, Fondo de la Real Colegiata de Santa María. Actas Capitulares, libro núm. 23. Sesiones del 16 y 23 de octubre de 1756. 
para afrontar necesidades perentorias y extraordinarias, siempre con el compromiso del reintegro demandando, en algunos casos, la entrega de intereses. Así, para extinguir la langosta de mediados del siglo XVIII, en Antequera se utilizaron cuantías de redención de censos, en concreto sabemos, por interposición de demanda, del uso de 940 ducados provenientes de la exoneración de cargas pendientes sobre el "cortijo de Archidona", a favor de unos particulares avecindados en la villa de Torrejonsillo. ${ }^{79}$ Para la devolución de ésta y otras deudas contraídas por el municipio antequerano se retoma el repartimiento vecinal. Particularmente, los 53,900 reales pendientes de restitución, por la crisis de 1756, van a tardar en completarse, mediante derrama, hasta la primavera de $1781 .^{80}$

A tenor de todo lo apuntado, no cabe duda del intenso dramatismo aparejado a una catástrofe agrícola provocada por acrídidos, máxime si tenemos presente las limitaciones materiales y técnicas de la sociedad en la Edad Moderna. Si aún en nuestros días, con todo tipo de prevenciones e insecticidas, los campos están expuestos a factores medioambientales adversos e incontrolables por el hombre, ${ }^{81}$ en la época que se trata cualquier tipo de incidencia adquiría tintes de hecatombe. No obstante, queda el reconocimiento de lucha contra la adversidad. El hombre se enfrenta con arados, rastrillos, buitrones y largas jornadas de recolección de insectos al mal que amenaza su subsistencia. Una batalla librada contra la naturaleza, para ellos una fuerza poderosa, gobernada a veces a capricho por poderes demoníacos, ante los cuales no vale sólo la lucha "armada", sino la contrición general por los pecados, la oración y la conjura de la maldición mediante exorcismos.

${ }^{79}$ AHma, Fondo Municipal. Actas Capitulares, libro núm. 1751. Sesión del 26 de marzo de 1760 y libro núm. 1752. Sesión del 9 de enero de 1761.

${ }^{80} \mathrm{Ibidem}$, libro núm. 1760. Sesión del 29 de mayo de 1769 y libro núm. 1772 . Sesión del 7 de marzo de 1781.

${ }^{81}$ La continua amenaza de la langosta en las sociedades contemporáneas es aún una realidad, a veces difícil de prevenir. Vid. Antonio Buj Buj,"La plaga de la langosta: Permanencia de un riesgo biológico milenario", Scripta Nova: Revista Electrónica de Geografía y Ciencias Sociales, núm. extra 12, 270, 2008 (Ejemplar dedicado a: X Coloquio Internacional de Geocrítica: Diez ańos de cambio en el mundo, en la Geografía y en las Ciencias Sociales 1999-2008). 
Mentalidad y religiosidad se dan la mano en éste como en otros muchos episodios acontecidos siglos atrás para explicar la realidad experimentada por un colectivo en un espacio-tiempo concreto. El miedo, el sufrimiento, la penuria van a estar contrarrestados por un fuerte componente ideológico de confianza en la intervención de la piedad divina. La historia de las calamidades públicas sufridas por la humanidad es la reconstrucción de los avances del conocimiento y la ciencia, pero también del rico universo de creencias y supersticiones de quienes nos precedieron y protagonizaron nuestro pasado.

\section{BIBLIOGRAFÍA}

Aguado, Isidro Benito, Vida histórica de la Langosta y manual de ayuntamientos para la extinción de este insecto, $3^{\text {a }}$ ed., Madrid, Imprenta de D. Norberto Llorenci, 1842.

Alberola Romá, Armando, Catástrofe, economía y acción politica en la Valencia del siglo XVIII, Valencia, Ed. Alfons el Magnànim, 1999. "Procesiones, rogativas, conjuros y exorcismos: El campo valenciano ante la plaga de langosta de 1756", Revista de Historia Moderna. Anales de la Universidad de Alicante, núm. 21, 2003, 383-410.

Aldrovandi, Ulisse, De animalibus insectos libri septem cum singularum iconibus ad vivum expressis [...] Bolonia, 1602.

Anes, Gonzalo, Las crisis agrarias en la España moderna, Taurus, Madrid, 1970.

Aponte Marín, Ángel, "Conjuros y rogativas contra las plagas de langosta en Jaén (1670-1672)”, en C. Álvarez Santaló, M.aJ. Buxó Rey y S. Rodríguez Becerra, coords., La religiosidad popular II. Vida y muerte: la imaginación religiosa, Barcelona, Anthropos, 1989, 554-562.

Azcatare Luxan, Isabel y Luis Maldonado Polo, "La plaga de la langosta y el tizón del trigo en la España ilustrada”, Llull, núm. 15, 1992, 309-330.

Barcia y Zambrano, Joseph, Despertador cristiano de sermones doctrinales sobre particulares assumptos, tomo III, Cádiz, Cristóbal de Requena Impresor, 1694. 
BARRAgÁn LANDAU, Juan José, “Las plagas del campo español y la devoción a San Gregorio Ostiense", Cuadernos de etnología y etnografía de Navarra, núm. 29, 1978, 273-297.

Barrero Baquerizo, Francisco, Historia de Antequera, manuscrito, 1732.

Blasco-Zumeta, Javier, "Breve nota sobre langosta y superstición hasta la ilustración del siglo Xvin", Boletín de la Sociedad Entomológica Aragonesa, núm. 20, 1997, 363-365.

Boada de las Costas y Figueras, Pedro, Adiciones y repertorio general de la práctica universal forense de los tribunales superior e inferior de España e Indias, Imprenta Ramón Ruiz, Madrid, 1793. En dicha obra se incluye la: Instrucción formada, sobre la experiencia, y practica de varios años, para conocer, y extinguir la langosta en sus tres estados de hovacion, feto, ò mosquito, y adulta: con el modo de repartir, y prorratear los gastos, que se hicieren en este trabajo, y aprobada por el consejo, año de mil setecientos y cinquenta y cinco.

BowLes, Guillermo, Introducción a la historia natural y a la geografía física de España, Madrid, Imprenta Real, 1782.

Buj Buj, Antonio, "La plaga de la langosta: Permanencia de un riesgo biológico milenario", Scripta Nova: Revista Electrónica de Geografía y Ciencias Sociales, número extra 12, 270, 2008 (Ejemplar dedicado a: x Coloquio Internacional de Geocrítica: Diez años de cambio en el mundo, en la Geografía y en las Ciencias Sociales 1999-2008).

Cabrera, Francisco, Descripción de la fundación, antigüedad, lustrey grandezas de la muy noble ciudad de Antequera, manuscrito, primera mitad del siglo XviI.

Ciruelo, Pedro, Tratado en el qual se repruevan todas las supersticiones y hechizos..., Barcelona, Sebastián Carmellas, 1628.

Covarrubias y Orozco, Sebastián, Tesoro de la lengua castellana o española, Madrid, Luis Sánchez, impresor del Rey N.S., 1611.

Cózar Gutiérrez, Ramón, "La administración municipal y el control de las plagas de langostas en Albacete a principios del siglo XVIII", Ensayos: Revista de la Facultad de Educación de Albacete, núm. 18, 2003, 47-60. 
EgIDO, Teófanes, "Los otros usos del agua: el agua bendita", en Alberto Marcos Martín, coord., Agua y sociedad en la época moderna, Valladolid, Universidad, 2009, 121-131.

Fernández, Cristóbal, Historia de Antequera desde su fundación hasta el año de 1800, Málaga, Imprenta del Comercio, 1842.

Gelabertó Vilagran, Martín, “Tempestades y conjuros de las fueras naturales. Aspectos mágico-religiosos de la cultura en la Alta Edad Moderna”, Manuscrits, núm. 9, enero 1991, 325-344.

Gomís, Alberto, "La divulgación de la Historia Natural en la España del siglo XVIII", Actas VIII Congreso de la Sociedad Española de Historia de las Ciencias y de las Técnicas, Universidad de la Rioja, 2004, 318-119 (309-330).

GonzÁlez Beltrán, Jesús Manuel, "Respuesta política frente a las adversidades naturales en el sector agrícola durante el siglo xvin", Revista de Historia Moderna. Anales de la Universidad de Alicante, núm. 23, 2005, 359-390.

Jiménez Patón, Bartolomé, Discurso de la langosta, que en el tiempo presente aflige, y para el venidero amenaza, Baeza, Pedro de la Cuesta Impresor, 1619.

LeÓn Vegas, Milagros, "Una simiente devastadora del agro antequerano: la plaga de langosta de 1620", Revista de Historia Moderna. Anales de la Universidad de Alicante, núm. 23, 2005 , 285-305.

, "Un enclave sacralizado en la urbe antequerana. La ermita, beaterio y hospital de la Vera-Cruz (siglos XvI-XVIII), Baetica, núm. 28, 2006, 433-456.

, Dos siglos de calamidades públicas en Antequera. Crisis epidémicas y desastres naturales (1599-1804), Antequera, Ayuntamiento, 2007, 268-269.

López Cordero, Juan Antonio y Ángel Aponte Marín, Un terror sobre Jaén. Las plagas de langosta XVI-XX, Jaén, Ayuntamiento, 1993. López Cordero, Juan Antonio, "Magia, superstición y religión en el agro jiennese. Las plagas de langosta”, en J. La Torre García y J.C. Sánchez León, eds., Magia y Religión en la Historia, Jaén, UNED, 1997, 101-121. 
MArín López, Rafael, "Noticias sobre una plaga de langosta en Granada en 1670 y 1671", Actas del VII Congreso de ProfesoresInvestigadores. Hespérides, Motril, 1988, 245-257.

Montemayor, Julián, "Les invasions de sauterelles dans l'Espagne intérieure" en B. Bennassar, ed., Les catastrophes naturelles dans l'Europe medievale et moderne, Presses Universitaires du Mirail, Toulouse, 1996, 261-269.

Novísima Recopilación de las leyes de España [...] mandada formar por el Señor D. Carlos IV, Impreso en Madrid, 1805, tomo II, libro VII, título xxxI: "De la extinción de animales nocivos y langosta".

QuiŃones, Juan de, Tratado de las langostas, muy útil y necessario, en que se tratan cosas de provecho y curiosidad para todos los que profesan letras divinas y humanas, y las mayores ciencias..., Madrid, Luis Sánchez, impresor del Rey, 1620.

RoldÁn, Jimeno Aranguren, "Configuración de una identidad hagiográfica popular: la leyenda de San Gregorio Ostiense”, Zainak, núm. 22, 2003, 89-101.

Rodríguez Molina, José, "Los 'insecticidas' en la etapa precientífica”, Boletín del Instituto de Estudios Giennenses, núm. 153, 1994, 685-743.

Rubio Vela, Agustín, "Presencia de la langosta. Plagas en la Valencia Bajomedieval", Saitabi, núm. 47, 1997, 269-288.

Sánchez Salazar, Felipa, Extensión de cultivos en España en el siglo XVIII, Madrid, Siglo Veintiuno, 1988.

SAnz Larroca, Juan Cosme, Las respuestas religiosas ante las plagas del campo en la España del siglo XVII, UNED, 2008.

, "Aguas milagrosas contra plagas en la España del siglo xvıı", Tiempos Modernos (revista electrónica), núm. 20, 2010/11.

Sarriá Muñoz, Andrés, Religiosidad y política. Celebraciones públicas en la Málaga del siglo XVIII, Málaga, Gráficas San Pancracio, 1996.

Sierra Pérez, José, "La música en el Monasterio de Guadalupe (algunas reflexiones en torno a la solemne procesión de la rogativa por la langosta en 1755)", Arts e Sapientia, núm. 0, 1999, 83-102. 
Sistach, Xavier, Bandas, enjambres y devastación. Las plagas de langosta a través de la historia, Córdoba, Almuzara, 2007.

Tarifa Fernández, Adela, Manuel Morales Romero y Enrique García García, "La ciudad de Úbeda a comienzos del siglo xviII. La plaga de langosta de 1709", Actas del X Congreso de Profesores-Investigadores. Hespérides, Sanlúcar de Barrameda, 1991, 299-308.

Tomás y Valiente, Francisco, "Delincuentes y pecadores", en vV. AA., Sexo barroco y otras transgresiones premodernas, Madrid, Alianza Editorial, 1990, 11-31.

VÁzquez Lesmes, Rafael y Cándido Santiago Álvarez, Las plagas de langosta en Córdoba, Córdoba, Cajasur, 1993.

Zarco Cuevas, Julián, "Pleito que se puso en la Abadía de Párraces para el exterminio de la langosta”, Boletín de la Real Academia de la Historia, tomo 100, Madrid, 1932, 313-348.

Zepeda y Vivero, Juan Antonio, Agricultura metódica, acomodada a la práctica del pais, con varias noticias acerca de la naturaleza, propagación y extinción de la langosta, Madrid, oficina de don Benito Cano, 1791.

Zurita, Gerónimo, Anales de la Corona de Aragón, Zaragoza, Herederos de Pedro Lanaja y Lamarca, 1610.

FECHA DE RECEPCIÓN DEL ARTículo: 21 de junio de 2011

FECHA DE ACEPTACIÓN Y RECEPCIÓN DE LA VERSIÓN FINAL: 8 de agosto de 2011 